\title{
Individual and global social responsibility levels of social studies pre-service teachers in terms of different variables
}

\author{
Melek Körükcüi ${ }^{1}$, Zafer Tangülü $^{2}$ \\ ${ }^{1}$ Faculty of Education, Niğde Ömer Halisdemir University, Turkey \\ ${ }^{2}$ Faculty of Education, Muğla Sitki Koçman University, Turkey
}

\section{Article Info \\ Article history: \\ Received Mar 13, 2020 \\ Revised Jun 18, 2021 \\ Accepted Jul 12, 2021}

\section{Keywords:}

Global social responsibility Individual social responsibility

Social studies

Teacher candidate

\begin{abstract}
The purpose of this research was to determine the individual and global social responsibility levels of social studies pre-service teachers in terms of different variables. The research was in survey model. The study group of the research consisted of 179 pre-service teachers who studied at Social Studies Teaching Program in the Faculty of Education at Niğde Ömer Halisdemir University, Turkey in the 2019-2020 academic year. Data collection tools used in the study are a Demographic Information Form developed by the researcher, Individual Social Responsibility Scale and Global Social Responsibility Scale. The data were analyzed through SPSS 20. The results of the study showed that the social studies teacher candidates' levels of individual social responsibility are high while those of global social responsibility are at medium level. It is also found that there is a significant difference in the individual and global social responsibility levels in terms of gender in favor of female pre-service teachers while there is no significant difference in terms of age variable. Also, the results show that the individual and social responsibility levels of pre-service teachers who have foreign friends are higher than those who do not have foreign friends. Another result of the study is that individual social responsibility levels predict social responsibility levels.
\end{abstract}

This is an open access article under the CC BY-SA license.

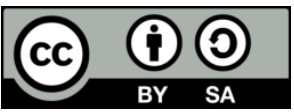

Corresponding Author:

Melek Körükcü

Faculty of Education

Niğde Ömer Halisdemir University

Niğde, Turkey

Email: melekkorukcu@ohu.edu.tr

\section{INTRODUCTION}

Responsibility is not an innate but a learned feeling as from childhood. It can be frequently seen in almost every individual, organizational and social aspect of daily life. Judgmental statements such as "responsible person", "what an irresponsible person" or "they are unaware of their responsibilities" are frequently heard expressions. Apart from such judgements, people are surrounded with various responsibilities in accordance with their social standings within their communities. Responsibility enables people to gain the motivation to fulfill their duties in time without waiting for exposure to an external stimulus or factor. Responsible people have the wisdom, competence to make decision freely and willpower required for this. They can share their actions and behaviors with other individuals with whom they interact and compromise their behaviors without hesitation when necessary. Because responsibility is the actualized form of ethical values. The struggle to live in a better World by taking care of oneself and their social surroundings with these activities makes responsibility more binding [1]. This compulsion appears as formal and informal responsibilities. Protecting one self's health, fulfilling their roles within the family, keeping the 
environment clean and giving support to their friends are among the informal responsibilities. On the other hand, formal responsibilities include one's fulfilling their tasks at workplace, obeying the laws, paying taxes and doing civic duties [2]. The sense of both formal and informal responsibility requires being accountable and completing a task assigned to an individual regardless of the existing situations and conditions. This is the natural result of the relationship between the ideal rules that the society wants to achieve and the existing social reality [3].

According to Bowen [4], who was one of the first to define the concept of social responsibility, social responsibility consists of all the obligations of enterprises to determine and implement policies, to make decisions and to fulfill their actions within the scope of both their own benefits and social values and expectations for improving social life. Social responsibility is also an individual's responsibility to other individuals. It begins with the inclusion of individual responsibilities to society. Because social responsibility is social behavior that will be done devotedly for the benefit of society. These behaviors consist of measures taken against the harmful effects that occur as a result of performing the activities required to live together. Behaviors such as being a member of non-governmental organizations, sharing, being in cooperation with others, dealing with the well-being and welfare of other individuals, helping others and internalizing all these behaviors are carried out with the sense of social responsibility [5], [6].

Individual social responsibility is the contribution of individuals to the solution of the problems observed or encountered in the society with financial or intangible volunteering activities. People with individual social responsibilities put the benefit of the society ahead rather than protecting their own interests. These behaviors are not included in the activities that businesses, various institutions and the state perform within the scope of social responsibility. It is the awareness of how effective individual actions are in society [7]. With this awareness, individuals with individual social responsibility give priority to the interests of the society rather than their own interests. Because the first dimension of individual social responsibility is the moral personality internalized by the individual [8]. Individuals with this personality are expected to work for the society, donate money to charity activities, help other individuals in social matters, be honest in all matters, adopt an environmentally sensitive lifestyle and be in contact with local people [9].

With the increasing influence of globalization since the 20th century, the difference between local and global borders has started to disappear markedly. This has increased interdependence and paved the way for intense and rapid social, political, economic, cultural and military relations. The concept of distance has gained new meanings with the effect of globalization. While an event on local basis affects another event miles away, an event that takes place on a global basis also affects the local [10]. Globalization has led to unifications as well as divisions, creating earthly dimensions [11] which have caused the content of responsibility to be handled globally and more broadly. Global social responsibility is to act with a sense of responsibility towards nature, beings, living beings and individuals. It requires individuals to feel the responsibility of any task such as environmental cleaning and cooperation on local basis as if to cover the whole world. Achieving the desired success in fighting global problems will be enabled by individuals who internalize global social responsibility and make it a part of their personality against all negative situations affecting humanity [12], [13] because responsibility is closely related to the value judgments of the society. Recognizing other individuals, respecting their values and accepting their assets are the most basic characteristics of individuals with global social responsibility.

Social Studies Course is related to the acquisition of skills, attitudes and knowledge about the concept of responsibility [14]. The purpose of the Social Studies Curriculum is to raise individuals who have adopted national and moral values by improving the competencies they have achieved at primary school, who exercise their rights and fulfil their responsibilities and who have achieved the basic skills and competencies mentioned in Turkish Qualifications Framework and particular to specific disciplines. Responsibility value is one of the root values in the Social Studies Curriculum [15]. The values that individuals have constitute the ground for effective communication with other individuals and determining their status and social positions in the society [16]. Achievements and values are included in the program interrelatedly. Values have an important place among the main elements that make up the culture for individuals and societies. One of the biggest goals of education is to transfer the values that society has created jointly to new generations and to ensure social integrity [17]. During this transfer, the value of responsibility is evaluated based on whether individuals complete their duties and endure the consequences of their behaviors. Because the fact that an individual performs the assigned tasks in a timely and complete manner indicates that sense of responsibility has developed [18].

Teachers, whom students take as role models in almost every issue, have a favorable position in value transfer and value education. However, teachers should internalize values and be competent in making students gain these values. Incompetency of teachers in this respect may cause students not to learn some values, their current values to become blunt, and even some values to disappear [19]. The reason for choosing social studies teacher candidates as the study group in the study is that the current attitudes and thoughts of

The investigation of individual and global social responsibility levels of social studies ... (Melek Körükcü) 
the pre-service teachers give clues about their future behaviors and attitudes. Because it will be possible to make the earth a more livable planet only by instilling a sense of individual and global social responsibility in future generations. Therefore, the aim of this study is to determine the individual and global social responsibility levels of social studies pre-service teachers, whose job is to enable their students to gain responsibility value in primary and secondary schools.

The research questions determined in accordance with this purpose are as: 1) What are the individual and global social responsibility levels of social studies pre-service teachers?; 2) Do the individual and global social responsibility levels of social studies pre-service teachers differ in terms of gender variable?; 3) Do the individual and global social responsibility levels of social studies pre-service teachers differ in terms of age variable?; 4) Do the individual and global social responsibility levels of social studies pre-service teachers differ in terms of having a foreign friend?; 5) Do the individual and global social responsibility levels of social studies pre-service teachers affect their perceptions about globalization?; 6) Do the individual social responsibility levels of pre-service teachers predict their levels of global social responsibility?

\section{RESEARCH METHOD}

This research, which examines the relation between the individual and global social responsibility levels of social studies pre-service teachers, this study was based on the relational survey model within the general survey model. Survey is a research approach that aims to describe a past or present situation as it is. Relational survey models are research models that aim to determine the presence and/or degree of change between two or more variables [20], [21].

\subsection{Study group}

The study group of the research consists of 179 teacher candidates (97 female and 82 male) who were studying at the Social Studies Teaching program in Faculty of Education at Niğde Ömer Halisdemir University, Turkey in the 2019-2020 academic year. The study group was selected on a voluntary basis through simple random method. The demographic information about the study group is shown in Table 1.

Table 1. The demographic information about the study group

\begin{tabular}{llcc}
\hline \multirow{2}{*}{ Demographic information } & \multicolumn{2}{c}{ Experiment } \\
& Female & f & $\%$ \\
\hline \multirow{2}{*}{ Gender } & Male & 97 & 54.2 \\
& 1st Grade & 82 & 45.8 \\
Grade & 2nd Grade & 13 & 7.3 \\
& 3rd Grade & 67 & 37.4 \\
& 4th Grade & 41 & 22.9 \\
Age & Aged 20 and below & 58 & 32.4 \\
& Aged 21 & 46 & 25.7 \\
& Aged 22 and above & 83 & 27.9 \\
& Illiterate & 46.4 \\
Mother's educational attainment & Primary school & 96 & 11.7 \\
& Secondary school & 33 & 18.4 \\
& Lycee & 22 & 12.3 \\
& University & 7 & 3.9 \\
& Illiterate & 10 & 5.6 \\
Father's educational attainment & Primary school & 66 & 36.9 \\
& Secondary school & 37 & 20.7 \\
& Lycee & 44 & 24.6 \\
Having a foreign friend & University & 22 & 12.3 \\
& Very interested & 42 & 23.5 \\
& Moderately interested & 84 & 46.9 \\
& Little interested & 35 & 19.6 \\
& Uninterested & 18 & 10.1 \\
& Yes & 80 & 44.7 \\
& No & 99 & 55.3 \\
& Yes & 14 & 7.8 \\
& No & 165 & 92.2 \\
\hline \multirow{5}{*}{ Interest in global issues } & & &
\end{tabular}




\subsection{Data collection tools}

Data collection tools used in the research are demographic information form, individual social responsibility scale, and global social responsibility scale. The scales are tested in terms of reliability and the results of the analysis are given in Table 2. The Global Social Responsibility Scale was developed by Başer and K1lınç [22]. The scale, which is 5-Likert type, consists of 32 items and four sub-dimensions. These subdimensions are action-oriented responsibility, ecological responsibility, altruistic responsibility and national responsibility. The reliability coefficient obtained for the entire scale in this research is .87 .

The Individual Social Responsibility Scale was developed by Eraslan [7]. The scale is 5-Likert type and consists of 32 items. It involves social responsibility awareness, environmental responsibility, social cooperation, sensitivity, disadvantaged group awareness, social interest, volunteerism, foresight, and social responsibility sub-dimensions. The reliability coefficient for the whole scale obtained in this research was found .89

Table 2. Reliability test results for individual social responsibility and global social responsibility scale sub-

\begin{tabular}{cc}
\multicolumn{2}{c}{ dimensions } \\
\hline Scale & Cronbach's alpha \\
\hline Individual social responsibility & .89 \\
Global social responsibility & .87 \\
\hline
\end{tabular}

\subsection{Data analysis}

The data obtained in the research were analyzed with SPSS 20. Arithmetic mean, standard deviation and standard error values regarding the levels of global and individual social responsibility were calculated within the scope of the research. The data were analyzed through t-Test for unrelated samples (Independent Samples t-Test) in terms of gender and having a foreign friend. The differences between the scores of the participants in terms of age and their interests in globalization were analyzed through one-way analysis of variance (One-Way ANOVA) for unrelated samples.

\section{RESULTS}

\subsection{Findings the 1st sub-problem}

The average standard deviation and standard error values obtained from the scales were investigated in order to find the answer to the first sub-problem of the research, "What are the individual and global social responsibility levels of social studies pre-service teachers?" The findings are presented in Table 3 .

It is indicated in Table 3 that the pre-service teachers' average scores taken from individual social responsibility $(\bar{x}=3.62)$ and global social responsibility scales $(\bar{x}=3.56)$ in general and the sub-dimensions of action-oriented responsibility $(\bar{x}=3.83)$, ecological responsibility $(\bar{x}=3.78)$ and altruistic-responsibility $(\bar{x}=3.66)$ were "high". However, the levels of teacher candidates' average scores were found to be "medium" in the national responsibility dimension of the global social responsibility scale. In line with this finding, it can be said that pre-service teachers' social responsibility perceptions were developed both individually and globally.

Table 3. Arithmetic mean, standard deviation and standard error values

\begin{tabular}{cccccc}
\hline Scale/Sub-dimensions & $\mathrm{n}$ & $\bar{x}$ & $\mathrm{ss}$ & $\mathrm{sh}_{\mathrm{x}}$ & Level \\
\hline Individual social responsibility & 179 & 3.62 & .54 & .04 & High \\
Action-oriented responsibility & 179 & 3.83 & .62 & .04 & High \\
Ecological responsibility & 179 & 3.78 & .73 & .05 & High \\
Altruistic responsibility & 179 & 3.66 & .68 & .05 & High \\
National responsibility & 179 & 2.98 & .62 & .04 & Medium \\
Global social responsibility & 179 & 3.56 & .50 & .03 & High \\
\hline
\end{tabular}

\subsection{Findings the 2nd sub-problem}

Independent Group t-test analysis was conducted between the average scores of the pre-service teachers in order to find the answer to the second sub-problem of the study: "Do the individual and global social responsibility levels of social studies pre-service teachers differ in terms of gender variable?" The findings obtained from the analysis are presented in Table 4.

Table 4 indicates that the difference between the pre-service teachers' average scores taken from individual social responsibility $\left(\mathrm{t}_{(177)}=4.19 ; \mathrm{p}<.001\right)$ and global social responsibility scales $\left(\mathrm{t}_{(177)}=3.84\right.$; 
$\mathrm{p}<.001)$ in general and the sub-dimensions of action-oriented responsibility $\left(\mathrm{t}_{(177)}=3.00 ; \mathrm{p}=.003\right)$, ecological responsibility $\left(\mathrm{t}_{(177)}=3.61 ; \mathrm{p}<.001\right)$ and altruistic-responsibility $\left(\mathrm{t}_{(177)}=3.56 ; \mathrm{p}<.001\right)$ were in favor of female pre-service teachers. However, no difference was found between the pre-service teachers average scores in terms of the national responsibility dimension of the global social responsibility scale $\left(\mathrm{t}_{(177)}=1.13 ; \mathrm{p}=.257\right)$. Considering these findings, it can be stated that both individual and global social responsibility levels of female pre-service teachers are higher than those of the male pre-service teachers.

Table 4. Independent group t-test results to determine scores differ according to gender variable

\begin{tabular}{|c|c|c|c|c|c|c|c|c|}
\hline \multirow{2}{*}{ Scale/Sub-dimensions } & \multirow[t]{2}{*}{ Groups } & \multirow[t]{2}{*}{$\mathrm{n}$} & \multirow[t]{2}{*}{$\bar{x}$} & \multirow[t]{2}{*}{ ss } & \multirow[t]{2}{*}{$\mathrm{sh}_{\mathrm{x}}$} & \multicolumn{3}{|c|}{ t-test } \\
\hline & & & & & & $\mathrm{t}$ & $\mathrm{sd}$ & $p$ \\
\hline \multirow{2}{*}{ Individual social responsibility } & Female & 97 & 3.77 & .55 & .05 & \multirow{2}{*}{4.19} & \multirow{2}{*}{177} & \multirow{2}{*}{.000} \\
\hline & Male & 82 & 3.44 & .48 & .05 & & & \\
\hline \multirow{2}{*}{ Action-oriented responsibility } & Female & 97 & 3.96 & .55 & .05 & \multirow{2}{*}{3.00} & \multirow{2}{*}{177} & \multirow{2}{*}{.003} \\
\hline & Male & 82 & 3.69 & .66 & .07 & & & \\
\hline \multirow{2}{*}{ Ecological responsibility } & Female & 97 & 3.96 & .73 & .07 & \multirow{2}{*}{3.61} & \multirow{2}{*}{177} & \multirow{2}{*}{.000} \\
\hline & Male & 82 & 3.57 & .68 & .07 & & & \\
\hline \multirow{2}{*}{ Altruistic-responsibility } & Female & 97 & 3.83 & .68 & .06 & \multirow{2}{*}{3.56} & \multirow{2}{*}{177} & \multirow{2}{*}{.000} \\
\hline & Male & 82 & 3.47 & .64 & .07 & & & \\
\hline \multirow{2}{*}{ National responsibility } & Female & 97 & 3.02 & .61 & .06 & \multirow{2}{*}{1.13} & \multirow{2}{*}{177} & \multirow{2}{*}{.257} \\
\hline & Male & 82 & 2.92 & .64 & .07 & & & \\
\hline \multirow{2}{*}{ Global social responsibility } & Female & 97 & 3.69 & .49 & .05 & \multirow{2}{*}{3.84} & \multirow{2}{*}{177} & \multirow{2}{*}{.000} \\
\hline & Male & 82 & 3.41 & .47 & .05 & & & \\
\hline
\end{tabular}

\subsection{Findings the 3rd sub-problem}

The third sub-problem of the study is stated with the question "Do the individual and global social responsibility levels of social studies pre-service teachers differ in terms of age variable?" ANOVA analysis was conducted to find out the answer of this question. The findings obtained as a result of the analysis are presented in Table 5.

Table 5. The results of the one-way variance analysis (ANOVA) conducted to determine scale scores differentiate in terms of age variable

\begin{tabular}{|c|c|c|c|c|c|c|c|c|c|c|c|}
\hline \multicolumn{2}{|c|}{$f . \bar{x}$ and $s s$ values } & \multicolumn{10}{|c|}{ ANOVA results } \\
\hline Scale/Sub-dimensions & Group & $\mathrm{n}$ & $\bar{x}$ & ss & Var. K. & KT & sd & $\mathrm{KO}$ & $\mathrm{F}$ & $\mathrm{p}$ & Difference* \\
\hline \multirow[b]{2}{*}{ Individual social responsibility } & 20 and under & 46 & 3.77 & .56 & Inter-group & 1.42 & 2 & .71 & & & \\
\hline & 21 & 50 & 3.57 & .54 & In-group & 52.02 & 176 & .29 & 2.41 & .093 & - \\
\hline \multirow{3}{*}{ Action-oriented responsibility } & 20 and under & 46 & 3.96 & .55 & Inter-group & 1.37 & 2 & .68 & & & \\
\hline & 21 & 50 & 3.87 & .63 & In-group & 67.91 & 176 & .38 & 1.77 & .172 & - \\
\hline & 22 and over & 83 & 3.75 & .64 & Total & 69.28 & 178 & & & & \\
\hline Ecological responsibility & 22 and over & 83 & 3.64 & .69 & Total & 97.12 & 178 & & & & \\
\hline \multirow{3}{*}{ Altruistic-responsibility } & 20 and under & 46 & 3.84 & .68 & Inter-group & 2.51 & 2 & 1.25 & & & \\
\hline & 21 & 50 & 3.68 & .70 & In-group & 80.89 & 176 & .46 & 2.73 & .068 & - \\
\hline & 22 and over & 83 & 3.55 & .65 & Total & 83.41 & 178 & & & & \\
\hline National responsibility & 20 and under & 46 & 2.98 & .71 & Inter-group & .13 & 2 & .06 & & & \\
\hline Global social responsibility & 22 and over & 83 & 3.48 & .49 & Total & 45.39 & 178 & & & & \\
\hline
\end{tabular}

*1: 20 and under, 2: 21, 3: 22 and over

It is revealed in Table 5 that there is no difference between the pre-service teachers' average scores in terms of individual social responsibility scale $\left(\mathrm{F}_{(2,176)}=2.41 ; \mathrm{p}=.093\right)$ and global social responsibility scale $\left(\mathrm{F}_{(2,176)}=2.93 ; \mathrm{p}=.056\right)$ as a whole and the sub-dimensions of dimensions of action-oriented responsibility $\left(\mathrm{F}_{(2,176)}=1.77 ; \mathrm{p}=.172\right)$, altruistic responsibility $\left(\mathrm{F}_{(2,176)}=2.73 ; \mathrm{p}=.068\right)$, and national responsibility $\left(\mathrm{F}_{(2,176)}=.17 ; \mathrm{p}=.840\right)$. On the other hand, a statistically significant difference was found between the average scores of the pre-service teachers aged '20 and under' and '22 and over' taken from the ecological responsibility dimension of the Global Social Responsibility Scale. The difference was found to be in favor of the pre-service teachers aged 20 and under $\left(\mathrm{F}_{(2,176)}=.4 .57 ; \mathrm{p}=.012\right)$. In this regard, it can be stated that the age variable does not have an effect on the pre-service teachers' perceptions about individual social 
responsibility and global social responsibility except for the ecological responsibility sub-dimension. However, it is seen that their perceptions about global social responsibility in terms of ecological responsibility become negative as they get older.

\subsection{Findings the 4th sub-problem}

Independent Group t-Test analysis was conducted in order to find the answer to the fourth subproblem of the study: "Do the individual and global social responsibility levels of social studies pre-service teachers differ in terms of having a foreign friend?" The findings obtained from the analysis are presented in Table 6.

When Table 6 is examined, it is seen that the pre-service teachers' average scores do not statistically differ in terms of the individual social responsibility $\left(\mathrm{t}_{(177)}=1.04 ; \mathrm{p}=.299\right)$ and global social responsibility $\left(\mathrm{t}_{(177)}=.95 ; \mathrm{p}=.340\right)$ scales as a whole and the sub-dimensions action-oriented responsibility $\left(\mathrm{t}_{(177)}=.33\right.$; $\mathrm{p}=.739)$, ecological responsibility $\left(\mathrm{t}_{(177)}=.27 ; \mathrm{p}=.783\right)$, altruistic responsibility $\left(\mathrm{t}_{(177)}=.59 ; \mathrm{p}<.554\right)$ and national responsibility $\left(\mathrm{t}_{(177)}=1.79 ; \mathrm{p}<.075\right)$. In line with this finding, it can be asserted that the pre-service teachers' having or not having foreign friends do not statistically affect their individual and global individual social responsibility perceptions. However, the average scores of the pre-service teachers who have foreign friends are seen to be higher than those of the pre-service teachers who do not have foreign friends, which may indicate that having a foreign friend increases social responsibility perception.

Table 6. Independent group t-test results to determine scale scores differ in terms of having a foreign friend variable

\begin{tabular}{|c|c|c|c|c|c|c|c|c|}
\hline \multirow{2}{*}{ Scale/Sub-dimensions } & \multirow{2}{*}{ Groups } & \multirow[b]{2}{*}{$\mathrm{n}$} & \multirow[b]{2}{*}{$\bar{x}$} & \multirow[b]{2}{*}{ ss } & \multirow{2}{*}{$\operatorname{sh}_{\mathrm{x}}$} & \multicolumn{3}{|c|}{ t test } \\
\hline & & & & & & $\mathrm{t}$ & sd & $\mathrm{p}$ \\
\hline \multirow{2}{*}{ Individual social responsibility } & Yes & 80 & 3.67 & .60 & .06 & \multirow{2}{*}{1.04} & \multirow{2}{*}{177} & \multirow{2}{*}{.299} \\
\hline & No & 99 & 3.58 & .49 & .05 & & & \\
\hline \multirow{2}{*}{ Action-oriented responsibility } & Yes & 80 & 3.85 & .69 & .07 & \multirow{2}{*}{.33} & \multirow{2}{*}{177} & \multirow{2}{*}{.739} \\
\hline & No & 99 & 3.82 & .56 & .05 & & & \\
\hline \multirow{2}{*}{ Ecological responsibility } & Yes & 80 & 3.80 & .82 & .09 & \multirow{2}{*}{.27} & \multirow{2}{*}{177} & \multirow{2}{*}{.783} \\
\hline & No & 99 & 3.77 & .66 & .06 & & & \\
\hline \multirow{2}{*}{ Altruistic-responsibility } & Yes & 80 & 3.70 & .75 & .08 & \multirow{2}{*}{.59} & \multirow{2}{*}{177} & \multirow{2}{*}{.554} \\
\hline & No & 99 & 3.64 & .62 & .06 & & & \\
\hline \multirow{2}{*}{ National responsibility } & Yes & 80 & 3.07 & .68 & .07 & \multirow{2}{*}{1.79} & \multirow{2}{*}{177} & \multirow{2}{*}{.075} \\
\hline & No & 99 & 2.90 & .56 & .05 & & & \\
\hline \multirow{2}{*}{ Global social responsibility } & Yes & 80 & 3.60 & .58 & .06 & \multirow{2}{*}{.95} & \multirow{2}{*}{177} & \multirow{2}{*}{.340} \\
\hline & No & 99 & 3.53 & .43 & .04 & & & \\
\hline
\end{tabular}

\subsection{Findings the 5th sub-problem}

The 5th sub-problem of the study is presented through the question "Do the individual and global social responsibility levels of social studies pre-service teachers affect their perceptions about globalization?" ANOVA analysis was conducted between to find out the relation between the average scores of pre-service teachers they took from the scales and their perceptions of globalization. The findings obtained from the analysis are presented in Table 7.

The data in Table 7 shows that the pre-service teachers' scores taken from individual social responsibility scale $\left(\mathrm{F}_{(3,175)}=0.68 ; \mathrm{p}=.560\right)$ and global social responsibility scale $\left(\mathrm{F}_{(3,175)}=1.98 ; \mathrm{p}=.117\right)$ as a whole, and action-oriented responsibility $\left(\mathrm{F}_{(3,175)}=1.35 ; \mathrm{p}=.258\right)$, ecological responsibility $\left(\mathrm{F}_{(3,175)}=1.04\right.$; $\mathrm{p}=.375)$, altruistic responsibility $\left(\mathrm{F}_{(3,175)}=1.50 ; \mathrm{p}=.216\right)$ and national responsibility $\left(\mathrm{F}_{(3,175)}=1.32 ; \mathrm{p}=.268\right)$ do not significantly differ in terms of their interests in globalization-related issues. In line with this finding, it can be stated that pre-service teachers' perceptions about both individual and global social responsibility do not change regardless of their levels of interest in globalization. 
Table 7. The results of the one-way variance analysis (ANOVA) scale scores differ according to the perception about the interest in globalization

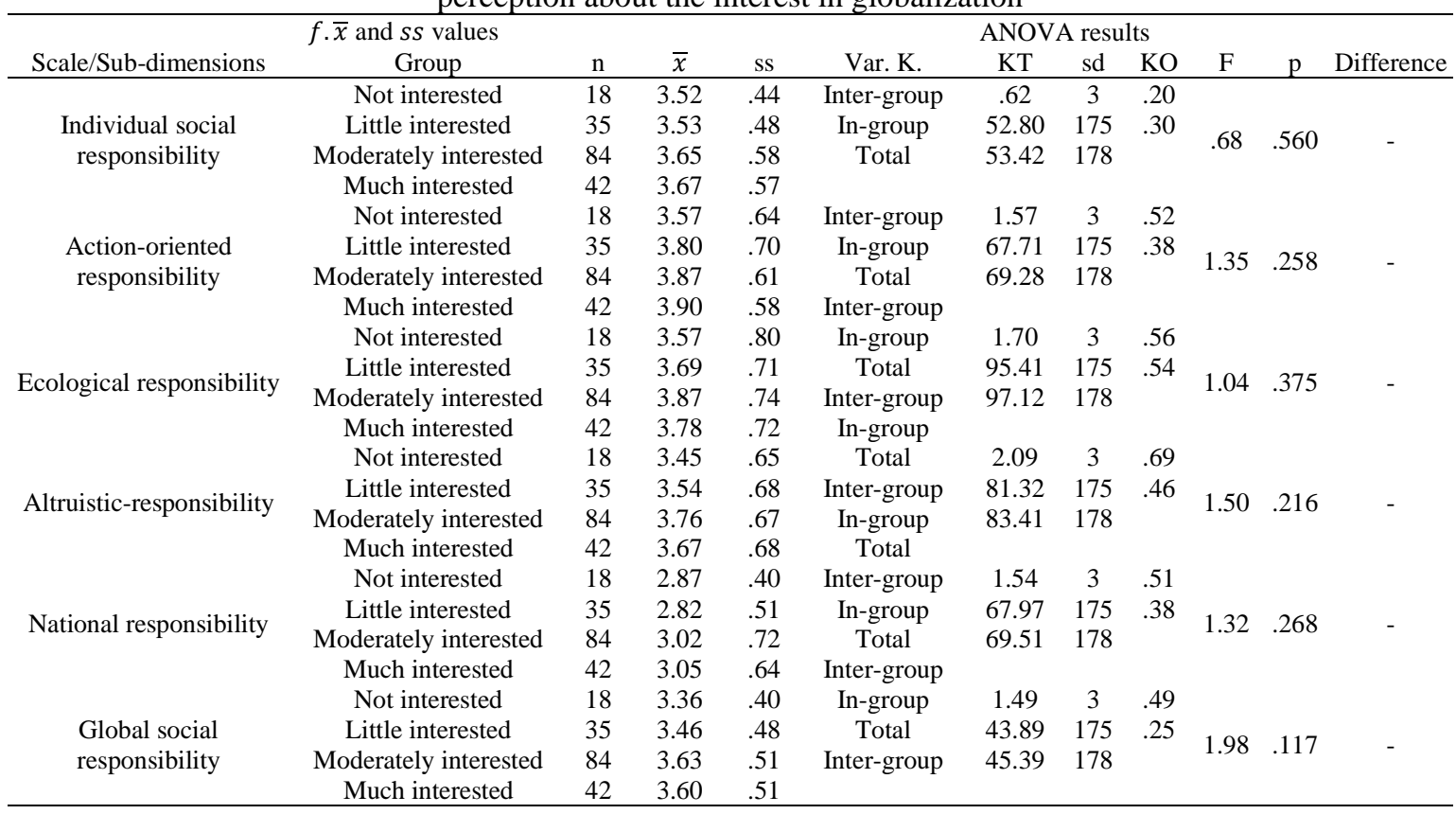

\subsection{Findings the 6th sub-problem}

Simple Linear Regression Analysis was conducted to find out whether the individual social responsibility levels of pre-service teachers predict their levels of global social responsibility, which refers to the 6th sub-problem of the study. The findings obtained from the analysis are presented in Table 8 .

According to the data in Table 8 , it is seen that there is a positive and medium-level relation between individual social responsibility and the action-oriented responsibility $(\mathrm{R}=.48 ; \mathrm{p}<.001)$ subdimension of the global social responsibility scale. Also, the relations of pre-service teachers' individual social responsibility levels $(\mathrm{R}=.76 ; \mathrm{p}<.001)$ with their levels of ecological responsibility $(\mathrm{R}=.70 ; \mathrm{p}<.001)$ and altruistic responsibility $(\mathrm{R}=.71 ; \mathrm{p}<.001)$ sub-dimensions of global social responsibility scale are found to be positive and high-level while a positive but low-level relation is observed between their individual social responsibility levels and their levels of national responsibility sub-dimension of the global social responsibility scale $(\mathrm{R}=.36 ; \mathrm{p}<.001)$. When it is examined to what extent the above-mentioned relations predict pre-service teachers' individual social responsibility levels, it is found that the relations predict $57 \%$ of variance across global social responsibility $(\mathrm{R} 2=.57), 23 \%$ of variance in action-oriented responsibility dimension $(\mathrm{R} 2=.23), 50 \%$ of variance in ecological responsibility dimension $(\mathrm{R} 2=.50), 50 \%$ of the variance in the altruistic responsibility dimension $(\mathrm{R} 2=.50)$ and $12 \%$ of the variance in the national responsibility dimension $(\mathrm{R} 2=.12)$. Considering this finding, it can be asserted that individual social responsibility contributes to global social responsibility.

Table 8. Results of simple linear regression analysis regarding the predictive role of teachers' environmental awareness levels on their environmental attitudes

\begin{tabular}{lllcccccc}
\hline Dependent variable & \multicolumn{1}{c}{ Independent variable } & $\beta$ & Standard error & $\mathrm{t}$ & $\mathrm{F}$ & $\mathrm{R}$ & $\mathrm{R}$ & $\mathrm{p}$ \\
\hline & Action-oriented responsibility & .42 & .05 & 7.33 & 53.86 & .48 & .23 & 000 \\
Individual social & Ecological responsibility & .52 & .03 & 13.35 & 178.32 & .70 & .50 & 000 \\
responsibility & Altruistic responsibility & .57 & .04 & 13.52 & 182.87 & .71 & .50 & 000 \\
& National responsibility & .31 & .06 & 5.12 & 26.29 & .36 & .12 & .000 \\
& Global social responsibility & .82 & .15 & 15.61 & 243.72 & .76 & .57 & .000 \\
\hline
\end{tabular}

\section{DISCUSSION}

Today, panhuman social problems such as poverty, violence, epidemics, refugee crises, global warming and migration are widely experienced. Society members are expected to have individual and global social responsibility in tackling these problems [23], [24]. Because social responsibility is a human-specific value which is not the result of a reward or punishment but the voluntary actions of the individual. These 
actions are not at the same level in every individual. In this context, the findings obtained from the research show that social studies teacher candidates have a high level of individual social responsibility while their global social responsibility levels are moderate. In studies with similar results, Kırılmaz, et al. [25] and Yetiş [26] also found that the global social responsibility levels of university students were at moderate level. Erdoğan and Erdem [27] concluded in his research that the individual social responsibility levels of the working group were high, which coincides with the result of our research. While social responsibility enables individuals to come together on a common ground in the society, global social responsibility makes people agree that the earth is a common area of use. Thanks to this agreement, individuals' lifelong knowledge and experience are offered to the service of the society and individual interests are put in the background. Subsequently, social contribution and social benefit are given priority so that the balance in the main components of the society is maintained. Social responsibility can be learned and taught by experience. Individuals who experience social responsibility are chosen to fulfill a task assigned by other individuals, fulfill the tasks assigned to them even if it is very difficult and take the consequences [28], [29].

The values of individuals provide socialization by forming a basis for the individual to communicate effectively with other individuals and to determine their status and social position in the society [30]. In order for socialization to take place, it is necessary to learn and apply social behavior patterns, roles, beliefs, attitudes and value judgments by all individuals. As a result, the identity of the individual is formed by ensuring the continuity of the current social organization. Unfortunately, it is observed that these occurrences often take place with sexist messages and behaviors [31], [32]. This observation is also confirmed by the finding obtained from this research. It has been determined that the individual and global social responsibility levels of female teacher candidates are higher than those of the male ones. In the literature, there exist various studies whose results coincide with the results of our research [12], [25], [26], [33]-[37]. However, no significant difference was found in terms of gender variable in the studies conducted with social studies teacher candidates [38]. It can be stated that this difference is due to the demographic characteristics of the sample groups of the studies. Because some behaviors in society are shaped by the society's mentality, values, culture, gender perspective and the roles assigned to men and women [39]-[41]. It can be claimed that psychological and emotional characteristics may serve to shape these roles by taking precedence over gender difference and basic value indicators of these differences.

In general, women's goals, sensitivities, desires, perspectives on ethical norms and responsibilities are unique to them, which drives them to adopt a different attitude in society. Politeness, responsibility, compassion and devotion, which are among these attitudes, are more developed in women. Considering the structure of our society, families give responsibility to girls at an earlier age than boys [41], [42]. In this context, it would not be wrong to state that both individual and global social responsibility levels of female teacher candidates are more developed than those of male teacher candidates.

It was determined that the individual social responsibility levels of the participants included in the study group did not differ significantly in terms of age, which is a finding that overlaps with the findings of Yetiş [26], Erdoğan and Erdem [27]. On the other hand, a significant difference was found in the global social responsibility levels of the participants only in the ecological responsibility sub-dimension in terms of the age variable and the difference was in favor of teacher candidates aged 20 and under. This finding reveals that the ecological responsibilities of teacher candidates should be increased by means of education with regulatory and innovative methods as they get older.

Wars, conflicts, nuclear disasters, environmental pollution have caused ozone depletion, global warming, and disruption of the ecological balance. Both the cause and the solution of these problems affecting all the nature and the living things in nature is the individual. Therefore, individuals should feel responsible for the prevention and solution of ecological problems. This feeling can be developed through education as responsibility is not an innate but a learned value which potentially exists within the individual [3], [43], [44].

The findings obtained from the study show that the individual social responsibility and global social responsibility levels of the teacher candidates who have foreign friends are higher than those of the teacher candidates without foreign friends, which may be the reflection of the cultural contact from which teacher candidates with foreign friends are affected. Because cultural contact is the main element that enables the individual to integrate in and interact with different cultures and different environments [45]. This interaction is experienced under various conditions and creates a situation of mutual influence through factors such as prejudices, stereotypes, intergroup relations, attitudes, beliefs and values [46]. It can be claimed that individuals' perceptions of individual and global social responsibility increase with this mutual interaction. Because social responsibility, whether individual or global, is individual investments made for the benefit of the whole world and it aims to ensure that all individuals lead a better life thanks to these investments [47].

Globalization is a phenomenon that has a transformative effect in all areas of social life due to its structure and internal dynamics. With globalization, the world has become more understandable and a whole 
where the concepts of time and space are tightened. This integrity has expanded the areas of responsibility and changed the individuals' perspectives on responsibility [48]. Research findings show that social studies teacher candidates' interests in globalization do not statistically affect their individual social responsibility and global social responsibility levels. In line with this finding, it can be asserted that teacher candidates have the interest, abilities and skills to adopt globalization but that their interests in issues related to globalization affect neither individual nor global social responsibility perceptions of them.

According to the data obtained from the research, it was determined that the individual social responsibility levels of social studies teacher candidates predicted their global social responsibility levels. This finding is regarded important as it shows that the teacher candidates are ready to take on responsibility by showing sensitivity to the problems of both their environment and the world they live in. Because individual social responsibility contributes to global social responsibility and addresses the problems of society from an international perspective. As a result, it can be claimed that social studies teacher candidates are aware of and have internalized their individual and global social responsibilities.

\section{CONCLUSION}

According to the results of the research, individual social responsibility levels of teacher candidates are high. Global social responsibility levels are moderate. The individual social responsibility level of female teacher candidates is higher than male teacher candidates. It was concluded that there was no correlation between the age of the teacher candidates and individual and social responsibility. Having a foreign friend increases global and individual responsibility. Issues related to globalization do not affect teacher candidates' individual and global responsibility. Changes should be made in the content of the courses related to social responsibility in the education programs of universities so that global social responsibility levels of teacher candidates can be increased. It should be aimed that all individuals gain a sense of individual and global social responsibility regardless of gender. In order to achieve this goal, efforts can be made to increase responsibility for male teacher candidates.

\section{REFERENCES}

[1] T. Lickona, "The return of character education," Education Leadership, vol. 51, pp. 6-11, 1993.

[2] T. Kılıç, Etik ve sosyal sorumluluk. Ankara, Gazi Yayınevi, 2017.

[3] Y. Özen, Sorumluluk eğitimi. Vize Yayıncılık, 2015.

[4] H. R. Bowen, Social responsibilities of the businessman. University of Iowa Press, 2013.

[5] B. Çakır, "SA 8000 sosyal sorumluluk standardının örgütsel bağlllık ve iş doyumuna olan etkileri," Master Thesis, Dokuz Eylül Üniversitesi, İzmir, 2006.

[6] P. C. Scales, D. A. Blyth, T. Berkas, and J. C. Kielsmeier, "The effects of service-learning on middle school students' social responsibility and academic success," The Journal of Early Adolescence, vol. 20, no. 3, pp. 332$358,2000$.

[7] L. Eraslan, "Bireysel sosyal sorumluluk ölçeğinin geliştirilmesi: geçerlik ve güvenirlik çalışması," Aile ve Toplum Dergisi, vol. 12, no. 7, pp. 81-92, 2011.

[8] K. Aquino and A. Reed, "The self-importance of moral identity," Journal of Personality and Social Psychology, vol. 83, no. 6, pp. 1423-1440, 2002.

[9] L. P. Dias, Beginnings human relation, 2012. [Online]. Available: http://2012books.lardbucket.org

[10] A. Giddens, Modernliğin sonuçları. Ayrıntı Yayınları, 2016.

[11] Z. Bauman, Küreselleşme: Toplumsal sonuçları. Ayrıntı Yayınları, 2015.

[12] F. Secgin and F. Yazıcı, "Tarih ve sosyal bilgiler öğretmen adaylarının kontrol odakları ve küresel sosyal sorumluluk düzeyleri arasındaki ilişki," Uluslararası Toplum Araştırmaları Dergisi, vol. 15, no. 8, pp. 1267-1277, 2018, doi: 10.26466/opus.436414.

[13] Y. Özen, Karakter ĕgitiminde ahlak ve sorumluluk. Gece Kitaplığı, 2014.

[14] H. Şirin, "Öğrencilerin sosyal sorumluluklarının geliştirilmesinde öğretmenlerin rolü,” Gazi Eğitim Fakültesi Dergisi, vol. 25, no. 1, pp. 301-31, 2005.

[15] Turkish Ministry of National Education. Social Studies Curriculum, Social information course teaching program (Elementary and Middle School 4th, 5th, 6th and 7th Grades). Ankara, 2018. [Online]. Available: http://mufredat.meb.gov.tr/Dosyalar/201812103847686SOSYAL\%20B\%C4\%B0LG\%C4\%B0LER\%20\%C3\%96\%C4\%9ERET\%C4\%B0M\%20PROGRAMI\%20.pdf.

[16] K. Yazici, S. Uslu, and S. Arık, "The investigation of the social entrepreneurship characteristics of social studies pre service teachers," Cogent Education, vol. 3, no.1, pp. 1-11, 2016, doi: 10.1080/2331186X.2016.1141455.

[17] R. Turan and K. Ulusoy, Farkl yönleriyle değerler eğitimi. Ankara, Pegem Yayıncılık, 2014.

[18] V. Aktepe, "5.sınıf öğrencilerinin sorumluluk değerinin geliştirilmesine yönelik bir performans görevi uygulamas1," Kastamonu Eğitim Dergisi, vol. 23, no. 4, pp. 1511-1534, 2015.

[19] R. Kaymakcan and H. Meydan, Ahlak ve değerler eğitimi. İstanbul, Değerler Eğitimi Merkezi, 2014. 
[20] Ş. Büyüköztürk, E. Kılıç Çakmak, Ö.E. Akgün, Ş. Karadeniz, and F. Demirel, Bilimsel araştırma yöntemleri. Pegem Akademi, 2010.

[21] N. Karasar, Bilimsel araștırma yöntemi. Nobel Yayıncılık, 2011.

[22] E. Başer and E. Kılınç, "Küresel sosyal sorumluluk ölçeği: geçerlik ve güvenirlik çalışması," Sakarya University Journal of Education, vol. 5, no. 3, pp. 75-89, 2015,

[23] Ş. H. Önal, "Bir sorumluluk eğitim programının lise dokuzuncu sınıf öğrencilerinin sorumluluk düzeylerine etkisi," Master Thesis, Uludă̆ Üniversitesi, Sosyal Bilimler Enstitüsü, Bursa, 2005.

[24] M. Zencirkıran, Küreselleşme, küresel sosyal sorunlar ve çözüm arayışları. Türkiye'nin Toplumsal Yapısı. (Ed. M. Zencirkıran). Dora Yayıncılık, 2013.

[25] H. Kırılmaz, S. Kılıç Kırılmaz, B. Demir, and Y. Marakçı, "Üniversite öğrencilerinin küresel sosyal sorumluluk düzeyleri üzerine bir araştırma," Social Sciences Studies Journal, vol. 4, no. 28, pp. 6197-6208, 2018, doi: 10.26449/sssj.1091.

[26] H. Yetiş, "Sağl1k bilimleri fakültesinde okuyan öğrencilerin bireysel sosyal sorumluluk düzeyleri ve etkileyen faktörlerin belirlenmesi,” Master Thesis, Sanko Üniversitesi, Gaziantep, 2019.

[27] E. Erdoğan and R. Erdem, "Hemşirelerin bireysel sosyal sorumluluk düzeyleri ile yaşam doyumunun demografik değişkenlere göre araştırılması," Süleyman Demirel Üniversitesi Sosyal Bilimler Enstitüsü Dergisi, vol. 3, no. 28, pp. 293-312, 2017.

[28] U. Oberst, "Educating for social responsibility," The Journal of Individual Psychology, vol. 65, no. 4, pp. 397-411, 2009.

[29] Y. Özen, "Kişisel sorumluluk bağlamında kariyer seçimini etkileyen sosyal psikolojik faktörler," Eğitim ve İnsani Bilimler Dergisi, vol. 3, pp. 81-96, 2011.

[30] K. Yazıc1, "Değerler eğitimine genel bir bakış," Türklük Bilimi Araştırmalarl, vol. 10, no. 19, pp. 499-522, 2006.

[31] E. Ersoy, "Cinsiyet kültürü içerisinde kadın ve erkek kimliği (malatya örneği)," Fırat Üniversitesi Sosyal Bilimler Dergisi, vol. 19, no. 2, pp. 209-230, 2009.

[32] S. Karaduman, "Modernizmden postmodernizme kimliğin yapısal dönüşümü," Journal of Yasar University, vol. 17 , no. 5, pp. 2886-2899, 2010.

[33] O. Akbaş, "Türk milli eğitim sisteminin duyuşsal amaçlarının ilköğretim II. kademedeki gerçekleşme derecesinin değerlendirilmesi," Doctoral Dissertation, Gazi Üniversitesi, Ankara, 2004.

[34] B. Ercan, "Ortaöğretim öğretmenlerinin sosyal sorumluluk anlayış ve uygulamaları: Antalya örneği," Master Thesis, Akdeniz Üniversitesi, Antalya, 2009.

[35] E. Altunay and M. Yalçınkaya, "Öğretmen adaylarının bilgi toplumunda değerlere ilișkin görüșlerinin bazı değişkenler açısından incelenmesi," Kuram ve Uygulamada Ĕgitim Yönetimi, vol. 17, no. 1, pp. 5-28, 2011.

[36] İ. Asar, "Lisansüstü öğrencilerinin kişilik yapılarıyla bireysel sosyal sorumluluk bilinçleri arasındaki ilişkiler," Master Thesis, Karabük Üniversitesi, Karabük, 2017.

[37] A. Kesici, "Lise öğrencilerinin sorumluluk düzeylerinin çeşitli değişkenlere göre incelenmesi," Gazi Üniversitesi Gazi Eğitim Fakültesi Dergisi, vol. 38, no. 3, pp. 965-985, 2018.

[38] E. Başer, "Sosyal bilgiler öğretmen adaylarının küresel sorumluluk düzeylerinin çeşitli değişkenler açısından incelenmesi," Master Thesis, Dumlupınar Üniversitesi, Kütahya, 2015.

[39] E. A. Fagenson, "At the heart of women in management research: Theoretical and methodological approaches and their biases," Journal of Business Ethics, vol. 9, pp. 267-274, 1990

[40] S. Üner, Toplumsal cinsiyet eşitliği, kadına yönelik aile içi şiddetle mücadelede temel eğitim seti. T.C. başbakanlık kadının statüsü genel müdürlüğ̈̈, unfpa, avrupa komisyonu türkiye delegasyonu. Duman Ofset, 2008.

[41] G.N. Powell and J.H. Greenhaus, "Sex, gender, and decisions at the family- work interface," Journal of Management, vol. 36, no. 4, pp. 1011-1039, 2010.

[42] E. H. Mudd, "Women's conflicting values," Journal of Marriage and Family Living, vol. 8, no. 3, pp. 50-65, 2002.

[43] B. Nazıroğlu, A. Gün, A. İ. Kılıç, and F. Kaya, "Temel ahlaki değerler," M. Köylü, Ed., Teoriden pratiğe değerler eğitimi. Nobel Yayınc1lık, 2016, pp. 181-252.

[44] T. Töremen, "The responsibility education of teacher candidates," Educational Sciences: Theory \& Practice, vol. 11, no, 1, pp. 263-277, 2011.

[45] C. Ward, S. Bochner, and A. Furnham, The psychology of culture shock. Hove, UK: Routledge, 2001.

[46] Ç. Kağıtçıbaşı, Benlik, aile ve insan gelişimi kültürel psikoloji. Koç Üniversitesi Yayınları, İstanbul, 2010.

[47] S. Berman, "Educating for social responsibility," Educational Leadership, vol. 48, no. 3, pp. 75-80, 1990

[48] S. Erdal, "Küreselleşme sürecinde refah devleti uygulamaları açısından isveç modelinin değerlendirilmesi," Doctoral Dissertation, Dokuz Eylül Üniversitesi, İzmir, 2012. 